\title{
FÁRASZTÓBERENDEZÉS KONCEPCIONÁLIS TERVEZÉSE
}

\author{
Tóth Dániel \\ tanársegéd, Miskolci Egyetem, \\ Szerszámgépészeti és Mechatronikai Intézet, Szerszámgépek Intézeti Tanszéke \\ 3515 Miskolc, Miskolc-Egyetemváros, e-mail: toth.daniel@uni-miskolc.hu
}

\begin{abstract}
Absztrakt
A csapágyak az egyik legszélesebb körben alkalmazott gépelemek. A müködési tulajdonságaik hatással vannak a teljes gép müködésére, ezért a vizsgálatuk rendkívül fontos. Jelen cikk a fárasztóvizsgálatokkal és egy csapágyfárasztó berendezés kifejlesztésével foglalkozik.
\end{abstract}

Kulcsszavak: fárasztóvizsgálat, tervezés, tesztberendezés

\begin{abstract}
Bearings are among the most widely used machine elements. Their operation properties have great impact on the function of the whole machine, therefore their investigation is very important. This paper focuses on fatigue tests and the development of a bearing fatigue device.
\end{abstract}

Keywords: fatigue test, design, test rig

\section{Bevezetés}

A gördülöcsapágyak müködés közbeni szemrevételezéses vizsgálata nehezen oldható meg, viszont például a zajszintből, a rezgésekből, a hőmérséklet emelkedéséből és a kenési feltételekből jó megközelítéssel megítélhető, hogy milyen zavar lépett fel egy adott csapágynál. A legszélesebb körben alkalmazott módszerek a folyamatos állapotfelügyelet, illetve a rezgésdiagnosztika. Előbbi során folyamatosan összehasonlító elemzéseket végeznek az adott csapágyon. Egy megfelelöen kiválasztott müködési jellemző aktuális értékét, a még frissen beszerelt értékkel összevetve megbecsülhető a csapágy várható maradó élettartama. A rezgésdiagnosztikai vizsgálatok során a gépelem rezgésképében található jellemző összetevők vizsgálatával állapítható meg a meghibásodás helye.

A csapágyak folyamatos és kiterjedt kutatásainak köszönhetően mára már nagy pontossággal meghatározhatók azok élettartama. Ennek ellenére is bekövetkezhet azonban a csapágy váratlan meghibásodása, mielőtt az még elérné névleges élettartamának végét. Ennek oka lehet például a vártnál nagyobb terhelő erő, az elégtelen vagy nem megfelelő kenőanyag használata, a hibás illesztések, melyek nem megfelelő belső hézagot eredményeznek, de a hibás tömítés vagy a gondatlan kezelés is okozhatja a meghibásodást. Minden hiba valamilyen csapágykárosodást okozhat. Ebből kifolyólag a meghibásodott csapágyat megvizsgálva, megállapítható a hiba oka és az ellenintézkedés a meghibásodás megismétlődésének elkerülésére. Alapvetően megkülönböztetünk primer és szekunder csapágykárosodásokat. A primer csapágyhibák közé tartozik a kopás, a benyomódás, az elkenődés, a felületi károsodás, a korrózió és a villamos áram okozta károsodások is. Szekunder hibák például a lepattogzás és a repedés. Az elsődleges hibák okozzák a másodlagos hibák megjelenését. Általánosságban elmondható, hogy egy tönkrement csapágyon a primer és szekunder hibák kombinációja fedezhető fel. Egy gördülőcsapágy maradó élettartamára annak fárasztó vizsgálatával és a kapott eredmények kiértékelésével kaphatunk információt. 
A fárasztóvizsgálatokat alapvetően két csoportba lehet sorolni. Az első csoportba az anyagvizsgálati fárasztások sorolhatók, ahol a fő cél az, hogy bizonyos szerkezeti anyag kifáradási jellemzőit megállapítsuk. A második csoportba sorolhatjuk az alkatrészek vagy gépelemek fárasztását. Az anyagvizsgálati fárasztások eredményeit bizonyos módon bizonyos géprészekre át tudjuk számítani, azonban az összetett és tagolt gépelemekre és szerkezetekre ez már nem végezhető el. Ezért alakultak ki az alkatrészek, gépelemek, szerkezetek fárasztóvizsgálatai [1]. Az ilyen vizsgálatoknál magát a kivitelezett géprészt vagy annak bizonyos mértékben egyszerüsített alakját fogják be egy fárasztógépbe. A befogás kialakítása olyan, hogy a géprész vagy gépelem terhelése - a lehetöségekhez képest - az üzemi terheléssel azonos. A fárasztott géprész lehet sorozatgyártásból kivett darab, vagy pedig gondosan elkészített és ellenőrzött, pontos méretủ, egyedi gyártású darab. Mind a két módszernek megvan az előnye. Ha a sorozatból vesszük ki a darabokat, akkor a tényleges alkatrész kifáradási viselkedését lehet szemléltetni és egyben az alkatrészek szilárdságának szórására is fény derül. A másik módszer egyöntetübb eredményt ad és bármilyen szerkezeti változás hatása megfigyelhető és érzékelhető $[2,3]$.

\section{Fárasztóberendezés tervezése}

A fárasztógépek fejlesztésének egyik főiránya olyan gép tervezése, amellyel megfelelő befogószerkezetek, a gép fogadó felületeire felszerelhető kisegítő gépegységek, állványok segítségével a legkülönfélébb vagy kizárólag egyféle gépelemek fárasztása elvégezhető. Az alkatrészek befogására különös gondot kell fordítani, hogy a befogási hely a fárasztóvizsgálatokat ne zavarja, a terhelés átadása és maga a terhelés üzemi körülményeknek megfeleljen. Gondolni kell arra is, hogy a befogott és fárasztott alkatrész olyan rezgésbe ne jöjjön, amely az üzemi terhelésben nem jelentkezik [4]. A fárasztógépek erőkifejtés szempontjából különböző típusúak. A terhelés elöállítható mechanikus, hidraulikus, elektromágneses, centrifugális vagy pneumatikus úton. A gépek túlnyomó többsége müködésük alapján lehet rezonancia elvén müködő, és lehet a terhelésváltozást erőhatás útján elöállító. A rezonancia elven müködő gépeken a vizsgálógépbe szerelt próbadarab a hozzácsatlakozó befogórészekkel lengörendszert alkot. A gerjesztő rezgéseket mechanikusan vagy elektromágnessel állítják elő. A gép vizsgálati frekvenciája megegyezik a lengőrendszer sajátfrekvenciájával [5]. A másik csoportba tartozó gépek a próbadarabra ható terhelést mechanikus, hidraulikus vagy pneumatikus erővel fejtik ki [6]. A fárasztógépek főként egyféle igénybevétel kifejtésére készülnek, azonban megfelelö befogószerkezet segítségével más jellegü terhelést is adhatnak a vizsgálandó gépelemnek [7-9]. A következőkben egy olyan fárasztóberendezés tervezése lesz bemutatva, amely a terhelésváltozást erőkifejtés útján állítja elő. A tervezendő fárasztóberendezés feladata egy új, még nem beépített csapágy járatása megfelelő fordulatszámon, adott radiális terhelőerő mellett.

A fárasztóberendezés funkciói az alábbiak szerint adhatók meg:

- Hajtónyomaték létrehozása: $\mathrm{M}_{\mathrm{f}}$,

- Terhelés: $F_{f}$,

- Erőmérés: $\mathrm{m}_{\mathrm{Ff}}$,

- Fárasztókészülék: $\mathrm{K}_{\mathrm{f}}$,

- Rezgésszigetelés: $\mathrm{r}$,

- Csapágy megfogás: $\mathrm{Cs}_{\mathrm{f}}$.

A funkciók feladatait a következők szerint fogalmazhatók meg:

- $\mathrm{M}_{\mathrm{f}}$ : a kísérleti berendezés meghajtása, amely képes forgómozgást biztosítani a vizsgált csapágynak,

- $\mathrm{F}_{\mathrm{f}}$ : a csapágyat adott mesterséges erővel kell terhelni, hogy az üzemi körülményeket a lehető 
legjobban közelítsük,

- $\mathrm{m}_{\mathrm{Ff}}$ : a terhelőerő ellenőrzése erőmérő szenzorral,

- $\mathrm{K}_{\mathrm{f}}$ : megfelelő csapágyazással ellátott géprész, amely képes átvinni a hajtónyomatékot és felvenni fárasztáshoz szükséges mesterséges erőt anélkül, hogy a kísérletet számottevően befolyásolná,

- r: a káros rezgéseket elszigetelése a fárasztási folyamat alatt,

- Csf: a csapágybefogás feladata, hogy átvigye terhelőerőt a csapágy külső gyürüjén keresztül és a fárasztást befolyásoló egyéb erők kizárása.

A fenti funkcióknak megfelelő elvi megoldásváltozatok láthatóak az 1. és 2. ábrán.

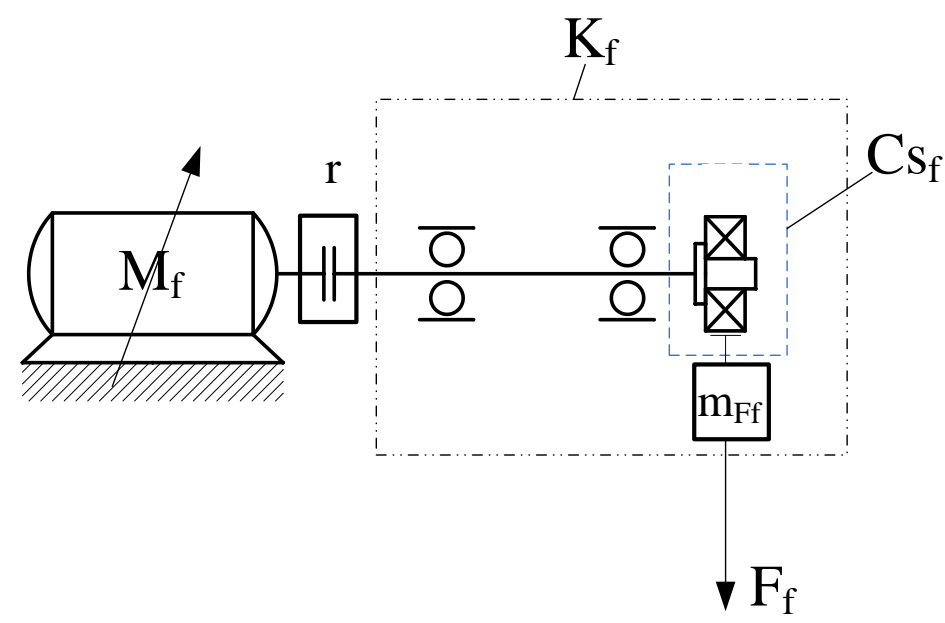

1. ábra. A fárasztó berendezés I. megoldásának elvi felépitése

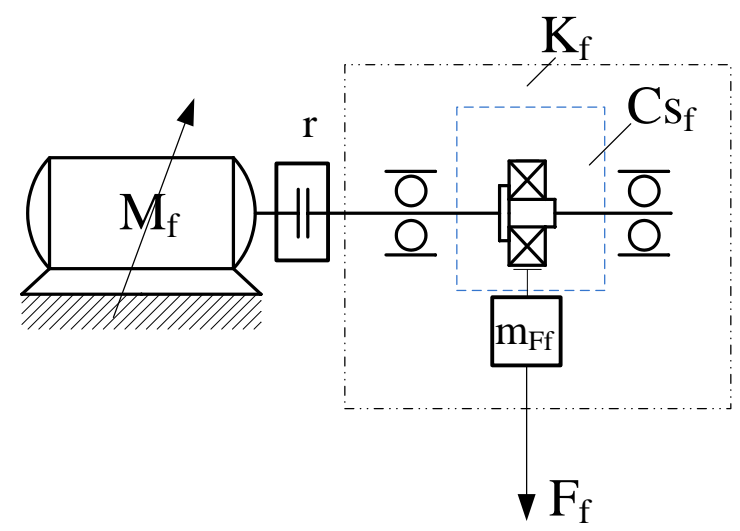

2. ábra. A fárasztó berendezés II. megoldásának elvi felépitése

Az ábrákon látható elvi megoldásokban az a közös, hogy a fárasztókészüléket egy gördülőcsapágyazással ellátott tengely képezi, amit egy fokozatnélküli fordulatszám szabályozható motorral hajtunk meg. A hajtómotor káros rezgéseinek elszigetelésére rugalmas tengelykapcsoló vagy rugalmas szíjhajtás alkalmazható. A vizsgált csapágyat az I. változat szerint konzolosan rögzítjük a berendezéshez, a II. változatnál pedig a csapágyazások közé szereljük. A tárgyalt változatoknál a terhelésválto- 
zást létrehozhatjuk rezonancia elven és húzó, vagy nyomó irányú erőhatás útján. Mindkét változat esetén radiális terhelőerő lett ábrázolva, amely irányítottságát tekintve lehet húzó, vagy nyomó irányú. A terhelésváltozást erőmérőszenzorral felügyeljük, amit a csapágymegfogó és az erőhatást kifejtő berendezés közé illesztjük. A vizsgált csapágy fárasztása során a fárasztó tengely múködik adott fordulatszámon, miközben a tengely csapjára szerelt csapágyra a hidraulikus henger az erőmérőn beállított $6[\mathrm{kN}]$ müterhelést fejt ki.

\section{3. Összefoglalás}

Jelen cikk keretei között csoportosítottuk a fárasztóvizsgálatokat, valamint ismertettük a fárasztóberendezések fejlesztése során felmerülö szempontokat. Ezt követően egy csapágyfárasztó berendezés két lehetséges elvi felépítését mutattuk be, illetve elemeztük a különböző változatokat.

\section{Köszönetnyilvánítás}

A cikkben ismertetett kutató munka az EFOP-3.6.1-16-2016-00011 jelü „Fiatalodó és Megújuló Egyetem - Innovatív Tudásváros - a Miskolci Egyetem intelligens szakosodást szolgáló intézményi fejlesztése" projekt részeként - a Széchenyi 2020 keretében - az Európai Unió támogatásával, az Európai Szociális Alap társfinanszírozásával valósul meg.

\section{Irodalom}

[1] Molnár, L., Varga, L.: Gördülöcsapágyazások tervezése, Müszaki Könyvkiadó, Budapest, 1977, p. 451.

[2] Zsáry, Á.: Méretezés kifáradásra a gépészetben, Müszaki Könyvkiadó, Budapest, 2005, p. 351.

[3] Tóth, D., Szilágyi, A., Takács, Gy.: Methods for the detection and analysis of bearing failures, Design of Machines and Structures, Vol. 8, No. 1 (2018) pp. 45-51., ISSN 1785-6892

[4] Tóth, S. G., Takács, Gy., Tóth, D.: Új generációs termékek élettartam tesztelö berendezésének kifejlesztése, Hazai és külföldi modellek a projektoktatásban, Budapest, 2018.

[5] Dömötör, F.: Rezgésdiagnosztika I., Dunaújvárosi Főiskola, Dunaújváros, 2008.

[6] Tóth, L.: Tranziens és kváziperiodikus folyamatok analizise az idö-frekvencia tartományban, $\mathrm{PhD}$ értekezés, Miskolc, 2011.

[7] Hegedűs, Gy., Barak, A., Barna, B., Demeter, P., Simon, G., Szilágyi, A., Takács, Gy.: Development of analyzing equipment of the remanent lifetime on roller bearings, MicroCAD 2010: XXIV. microCad International Scientific Conference: Section L: Machine and structure design, Miskolc, Hungary: University of Miskolc, (2010) pp. 47-52., ISBN:9789636619169

[8] Patkó, Gy., Takács, Gy., Barna, B., Demeter, P., Hegedűs, Gy., Barak, A.: A process for establishing the remanent lifetime of rolling element bearings, MicroCAD 2010: XXIV. microCad International Scientific Conference: Section L: Machine and structure design, Miskolc, Hungary: University of Miskolc, (2010) pp. 53-58., ISBN:9789636619169

[9] Takács, Gy., Patkó, Gy., Csáki, T., Szilágyi, A., Hegedűs, Gy.: Development of Mechatronic Systems at the Institute for Mechatronics at the University of Miskolc. 2006 IEEE International Conference on Mechatronics, pp. 326-331. https://doi.org/10.1109/ICMECH.2006.252548 